\title{
Knowledge of women living in Otwock county about breast cancer
}

\begin{abstract}
Breast cancer is one of the most common types of cancer in women. In 2012 alone, some 17000 women developed breast cancer and the condition accounted for 5574 deaths. Breast tumor poses a huge threat for women aged 46-65 (working age) and other age groups are at an only slightly lower risk. An early diagnosis of breast cancer would increase chances of survival, which means that it is essential to educate women about breast tumors, risk factors, symptoms and diagnosis.

The authors of this work aimed at assessing the knowledge of women residents of Otwock County about breast tumors. The study included a questionnaire including 31 questions, containing queries looking at women's knowledge of breast tumors and it was distributed to residents of Otwock County between September and October 2014.

An analysis of the questionnaire responses suggests what follows: (i) women of all ages are not knowledgeable enough about cancer; (ii) medical professionals, like general practitioners, gynecologists, pharmacists and even nurses should encourage women to learn more about tumors, (iii) women still do not know how to perform breast self-exams, (iv) women are aware of the fact that routine checkups are essential but they do not have them and also mistake the names of preventive programs for names of institutions and organizations that deal with fighting cancer, (v) women still do not know that mammogram tests are free of charge and in order to have them done, they do not need to have a referral.
\end{abstract}

Keywords: Breast cancer, risk factors, knowledge, Breast cancer prevention, the role of a pharmacist in sharing knowledge.

DOI: $10.1515 /$ pjph-2016-0012

\section{INTRODUCTION}

Breast tumors are one of the main oncologic burdens to developed countries and they are becoming a pressing problem these days [1]. A half of the overall number of breast tumor cases happens in developed countries, while most breast tumor-related deaths happen in underdeveloped countries $(60 \%)$. Some 330000 women were diagnosed with breast tumors in EU countries, while some 89000 died because of it. During the last 5 years, some 1.33 million women were diagnosed with breast cancer [2].

Another 22\% of Polish women are expected to develop breast cancer at some point in the future. Between 1999 and 2012, some 26474 women developed the condition in Masovian Voivodeship only, while some 36671 died because of breast tumor. Overall, both the mortality and morbidity rates for breast cancer in Masovian Voivodeship are much higher than in other regions of Poland [3]. The lowest rates are reported in Lubusz Voivodeship - some 4604 women developed cancer between 1999 and 2012 and some 6294 died because of breast tumor. In general, the rates of breast cancer development have a tendency to rise. In 2012, some 17000 Polish women developed breast cancer, out of which 5574 died. Some 10 years earlier, in 2002, the rates were as follows: 12130 women developed breast cancer and 4825 died [2]. These statistics show a $40 \%$ increase during the last 10 years (comparing 2002 and 2012) - over 5000 more women developed the condition and the mortality rate increased by $15 \%$.
On the one hand, this might indicate that breast cancer treatment methods are becoming increasingly effective, so that mortality rates are much lower than morbidity indexes. In addition, the increase in the number of breast cancer cases might indicate that women still know very little about breast tumors, their symptoms and risk factors.

Some $80 \%$ of breast cancer cases happen to women older than 50 , while some $50 \%$ of cases are diagnosed between the age of 50 and 69 . The risk of breast cancer increases along with age, at least up to the seventh decade of life, after which it decreases. The morbidity rates have increased over two times during the last three decades [2].

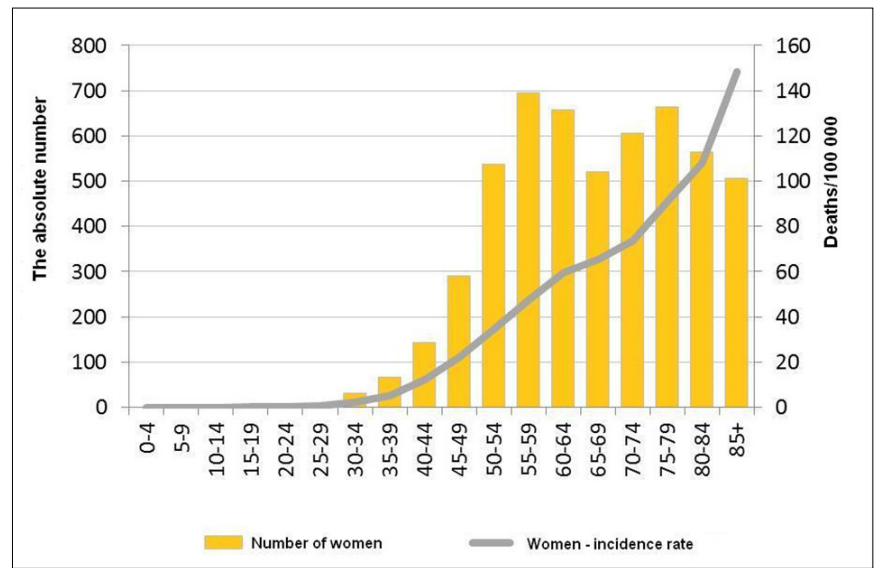

FIGURE 1. Breast tumor morbidity rates in Poland between 2008 and 2010, depending on age [2]. 
Over the last three decades, mortality rates for adult women belonging to the premenopausal age group (20-49 years) have increased 1.7 times. Women aged 50-69 are at the highest risk of developing the condition and the highest increase in the number of tumor cases has been reported during the last two decades (1990-2010). Since the 1990s, women in their 70s are no longer the group with the highest number of reported cases of breast cancer [2].

Breast cancer is responsible for some $13 \%$ of tumor-related deaths among Polish women [2]. In order to show the increase in the number of breast tumor mortality, one might use the number of deaths because of tumors in the 1960s. For instance, in 1965 breast tumor accounted for some 1938 deaths in Poland, while in 2012 it was 5574. This means, there was an increase of 2.8 times over 50 years [2].

Most breast cancer-related deaths happen to women after 50 $(90 \%)$, while the number of deaths in the following age groups remains on relatively similar levels (around 10\% deaths). The risk of death because of cancer systematically increases with age (Figure 1). It is estimated that the breast cancer morbidity indexes in Poland will soon reach the levels reported in West Europe and that it will exceed 20000 cases annually by 2020 [4].

It is not only prevention that plays a role here but also the knowledge how to detect cancer, awareness of the risk factors or preventive measures $[5,6]$.

\section{AIM}

The authors of the study aimed at checking the knowledge of female residents of Otwock about the risk factors or symptoms of breast cancer.

\section{MATERIAL AND METHODS}

Some 69 women all residents of Otwock county were subjects of the survey study, conducted between September and October 2014. The authors used an anonymous and voluntary survey containing 31 questions and the participants were chosen at random. The survey contained 6 questions regarding age, place of residence, education, professional status, number of children born, as well as the age at which the first birth happened. The correlations between the rank and quantitative variables (like age, place of residence) were checked using Spearman rank correlations. For statistical analyses, the Spearman rank correlation was used. The statistical significance level was estimated as $\mathrm{p}=0.005$.

\section{RESULTS}

Almost a half of the study participants were residents of Otwock (49.2\%) while others lived in Otwock county (15.3\%) or in the countryside (35.6\%). Most women had higher education $(44.1 \%)$ and secondary education $(39 \%)$. Some women had either professional education $(10.2 \%)$ or basic education (7\%). At the beginning, women were asked about their knowledge of breast self-diagnosis, namely, how often should the procedure be conducted. Most respondents (around 60\%) were able to provide correct number here, while some $24 \%$ claimed it should be done once a year and 14\% claimed it should be done once in a quarter. One person even claimed that there is no need for breast self-diagnosis.

The number of women knowing when the self-diagnosis should be conducted was not too high (39\%). Some $30 \%$ respondents said that it is not important, while another $10 \%$ claimed it should be done right after the period begins. A huge portion of the respondents was unable to provide an answer.

According to the respondents, it is hereditary factors risk factors that pose the most threat (some 90\%), while a half of them $(53.4 \%)$ claimed that taking hormonal drugs can boost the risk of breast cancer. Another $21 \%$ of the respondents pointed to various environmental factors, while only a few women knew that both diet $(5.2 \%)$ or alcohol consumption $(1.7 \%$ ) can boost the risk (Figure 2).

A little more than $80 \%$ of women knew that one of the initial cancer symptoms include lumps felt through palpation examination (81\%). Others symptoms included edemas (32.8\%), pain $(20.7 \%)$ or skin changes $(15.5 \%)$. Some $22 \%$ of the respondents claimed that the initial stage of breast cancer development is asymptomatic.

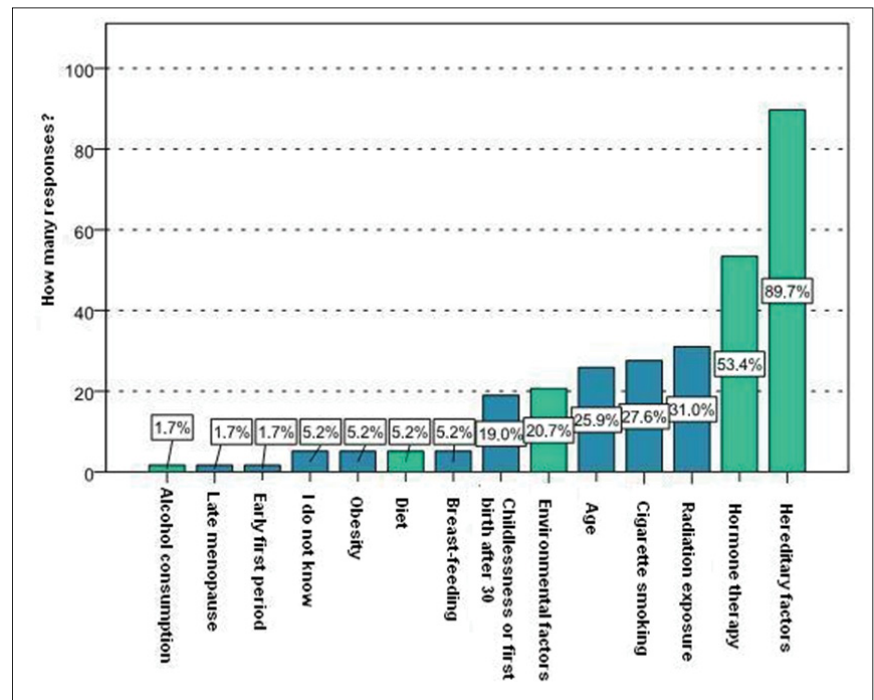

FIGURE 2. Risk factors for breast cancer, according to participants of the study (female residents of Otwock county).

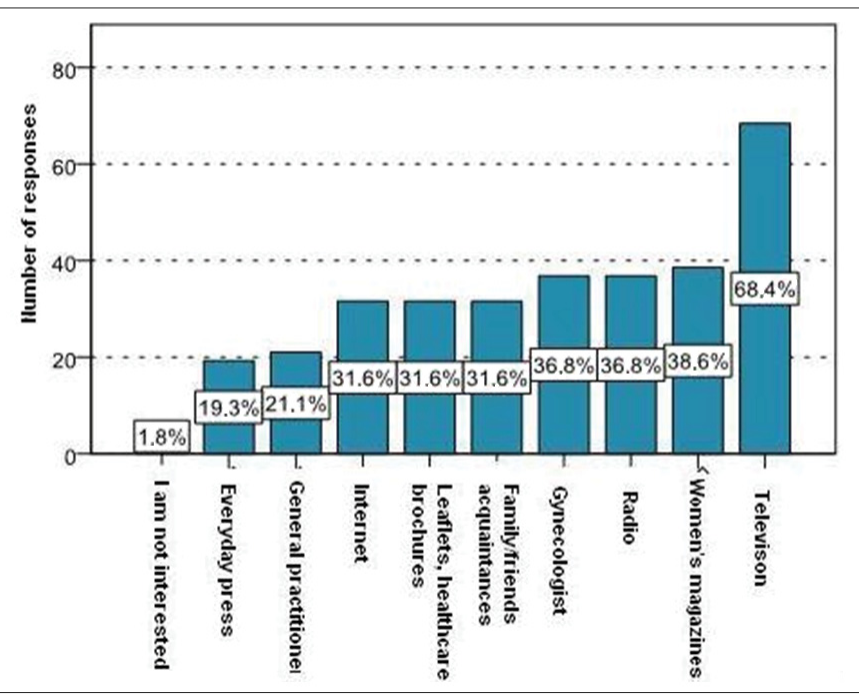

FIGURE 3. Where do the study participants receive their knowledge about prophylaxis and tumor treatment.

A little more than $70 \%$ of women claimed that a lump might be an indication of cancer at an advanced stage (70.7\%). Over a half of the respondents knew that discharge from the nipple (53.4\%) or changes in the way that breasts look (43.1\%) should be regarded as dangerous symptoms. Even less participants pointed to retraction of the nipple $(34.5 \%)$ or breast deformations (32.8\%). Many participants (19\%) were unable to mention 
any symptoms. One respondent even claimed that breast cancer at an advanced stage is asymptomatic. Participants pointed to television $(68.4 \%)$, female magazines $(38.6 \%)$, radio (36.8\%), gynecologist (38.6\%), family doctor $(21.1 \%)$, family or friends $(31.6 \%)$, informative leaflets $(31.6 \%)$ the Internet $(31.6 \%)$ or newspapers published daily $(19.3 \%)$ as their sources of knowledge about how to treat breast cancer.

Only two respondents ( $3.4 \%$ of all) knew that the free mammographic examinations require no doctor's referral. Others marked incorrect answers.

Most women knew that not only females who had a family history of breast cancer are at risk of developing the condition $(87.7 \%)$. Some $10.5 \%$ of respondents claimed that it is family history that determines this risk. Also, a huge portion of the respondents knew that not all lumps discovered in breasts mean breast cancer $(86.7 \%)$.

At the same time, only $60 \%$ of women knew that it is possible to prevent tumors. Some $22 \%$ of the respondents did not know how to answer such a question, while some $17 \%$ of the respondents claimed it is impossible to prevent tumors.

A half of the respondents (55.2\%) assessed their awareness of breast cancer as average. Others claimed that it is good (31\%) and some $14 \%$ that it is poor.

According to some $96.6 \%$ of the respondents, an early diagnosis might help one prevent breast cancer. Also, some $64.4 \%$ of the respondents claimed it was correct treatment, whilst only some $22 \%$ of them knew that age might be a factor as well.

It was reported that people at an older age have less knowledge about breast cancers than younger patients. This correlation is statistically significant $(\mathrm{p}=0.025)$. Women with higher education achieved higher results $(\mathrm{p}=0.006)$. At the same time, there was no correlation between the place of residence and one's knowledge, yet, the result was on the verge of the level of significance $(p=0.05)$. An analysis of the correlation coefficient suggests that residents of rural areas tend to know less than those from larger towns. However, as it was mentioned above, this correlation has no statistical significance.

TABLE 1. Values of correlation coefficients.

\begin{tabular}{llc}
\hline \hline \multirow{2}{*}{ Age: } & \multicolumn{2}{c}{ Total of points } \\
\hline \multirow{2}{*}{ Place of residence: } & Correlation coefficient & -0.293 \\
\cline { 2 - 3 } & Significance (bilateral) & 0.025 \\
\hline \multirow{2}{*}{\begin{tabular}{l} 
Education: \\
\cline { 2 - 3 }
\end{tabular}} & Correlation coefficient & -0.256 \\
\hline $\begin{array}{l}\text { How does a patient assess } \\
\text { her knowledge about breast } \\
\text { cancer? }\end{array}$ & Correlation coefficient & 0.352 \\
\cline { 2 - 3 } & Significance (bilateral) & 0.006 \\
\hline
\end{tabular}

The women that had a high opinion about their knowledge of breast cancer prophylaxis achieve relatively high results in the test they were dealing with $(\mathrm{p}=0.001)$.

Most of the respondents felt that to the idea of prophylaxis means preventing the illness (67.2\%), early diagnosis (58.6\%), regular check-ups (50\%), broadening the knowledge about health or illness $(48.3 \%)$ and one person had no idea what prophylaxis is $(1.7 \%)$.

\section{DISCUSSION}

The knowledge about risk factors is one the basic ways to prevent cancers. Research looking into this matter is being carried out at various medical centers in Poland, yet little is known about it. Most women point to genetic factors, which makes them think that in case they have no family history of cancer, there is nothing to worry about. These findings were confirmed by various researchers conducting studies all around Poland [5-7]. Lack of education, no matter what the age is, might be one of the reasons why women know so little of it $[8,9]$.

Also, women know very little about breast self-diagnosis - they do not know, when exactly should it be done or how often. The authors' own research has shown that over a half of the respondents know that the self-diagnosis needs to be done once a month, yet only $38 \%$ of them know it should be conducted right after their period. It is almost certain that were the questionnaire to ask about a particular number of days after the period has ended, the answers would be even more dissatisfying. Other respondents have provided incorrect answers about the right time for self-examination. Our findings have been confirmed by other researchers as well $[6,7,10]$.

Breast lumps are considered as one of the main symptoms of breast cancer $[9,10]$. The authors' own study has confirmed the findings of other researchers looking at the patients' knowledge. Over $70 \%$ of women claimed that lumps are one of the basic symptoms of breast cancer, while some $32.8 \%$ pointed to an edema. Over 53\% pointed to discharge from the nipple and $43.1 \%$ mentioned changes in the way that breasts look as symptoms of advanced cancer. Retraction of the nipple is a symptom of advanced cancer according to $34.5 \%$ of the respondents only. Zych B et al. [9] found something else in their study, some $59 \%$ of the respondents pointed to nipple retraction as a key symptom of cancer.

It might sound interesting that the respondents have some knowledge about both morbidity and mortality in Poland. Some $56.6 \%$ of the respondents provided a correct answer about female mortality and some $60.8 \%$ of women pointed to extremely high morbidity as correct. These findings may suggest that women are aware of this problem, yet they do not pay too much attention to it, possibly because they are afraid that they can develop the condition themselves.

Even though hereditary factors are pointed to as the main risk factor, some $87.7 \%$ of the respondents know that women who have no family history of breast cancer are at risk as well. Also, some $86.7 \%$ of the respondents knew that lumps do not necessarily mean breast cancer.

Only $3.4 \%$ of the respondents knew that the mammography refunded by NFZ (National Health Fund) can be done free of charge every two years and women aged 50-69 do not need to have a doctor's referral. The respondents mentioned gynecologists, general practitioners or nurses as those who decide about the need for mammography examination. Every $10^{\text {th }}$ woman did not even know that she can undergo such examination. This points to the fact that women know very little about it, as medical staff (general practitioners or gynecologists) rarely educate patients in this field. Other authors have found similar results $[6,11]$.

The television remains the main source of knowledge about cancer. Similarly to the findings of Paździor and Cichońska $[6,12]$, the authors of this study have noticed that it is mainly older women that regard television as the chief source of 
knowledge. Younger Polish women point to the Internet as their main source of information about breast cancer - this was confirmed by other authors as well $[5,10,11]$.

For many respondents, women's magazines, leaflets and family or friends were important sources of knowledge as well. Other authors have found these factors to have little significance $[10,11]$, yet some $17 \%$ of students participating in Wołowski's research pointed to their family as a source of knowledge about breast cancer.

There are some organizations and institutions dealing with breast cancer prophylaxis: the Amazon - PL: Amazonki (known to $59.6 \%$ of women), Pink Ribbon Campaign - PL: Kampania Różowa Wstażka (some 59.6\% of the respondents knew it). Significantly less women knew about Polish Oncology Association - PL: Polska Unia Onkologii (5.3\%) and Polish Association of Fighting Cancer - PL: Polski Komitet Zwalczania Raka (3.5\%). Some $17.5 \%$ of women knew none of these organizations which points to the fact that they do not care about breast cancer. When it comes to cancer control programs, Kampania Różowa Wstążka was pointed to as the most widely known one, similarly to the research published by Smolen. Interestingly enough, women have difficulties distinguishing particular names of organizations and institutions dealing with breast cancer. This means, they receive information about breast cancer, yet it is unorganized. Polish women tend to get lost in the amount of information, which is why they give up on prophylaxis. Yet, they are aware of the fact that an early diagnosis and correct treatment can hugely boost the chances of a successful treatment.

Both the authors' own research and the findings of other authors point to the fact that Poles lack the essential knowledge about cancer [5,6,9-11]. There is a need to maximize educational efforts, both in the mass media, as well as encouraging medical staff (doctors, nurses, pharmacists) to educate patients.

\section{CONCLUSIONS}

1. Women have rather little knowledge about breast selfexamination.

2. Women are aware that prophylaxis is important but they do not conduct the examinations.

3. Family doctors, gynecologists and pharmacists or other medical staff should be the basic source of knowledge about cancer.

4. There is a huge need to educate women about risk factors, symptoms or prophylaxis.

5. Women do not know that they can participate in mammographic screenings for free and that they do not need a doctor's referral for it.

\section{REFERENCE}

1. Sytuacja zdrowotna ludności. Polski Państwowy Zakład Higieny. Warszawa; 2012.

2. Krajowy Rejestr Nowotworów

3. Mazowiecki Rejestr Nowotworów

4. Didkowska J, Wojciechowska U, Zatoński W. Nowotwory złośliwe w Polsce w 2009 roku. Warszawa: Ministerstwo Zdrowia; 2011.

5. Wołowski T, Wróblewska P. Ocena wiedzy gdańskich studentek na temat profilaktyki raka piersi. Probl Hig Epidemiol. 2012;93:347-9.

6. Pażdzior A, Stachowska M, Zielińska M. Wiedza kobiet na temat profilaktyki raka piersi. Now Lek. 2011;80(6):419-22.

7. Nita R, Łeśniczak B, Słomka B, et al. Wiedza i zachowania zdrowotne kobiet $\mathrm{z}$ województwa łódzkiego $\mathrm{w}$ zakresie profilaktyki raka piersi. Pielęg XXI w. 2010;30/31(1-2):5-8.

8. Adamowicz K, Zaucha JM, Majkowicz M. Ocena wiedzy pacjentek Poradni Profilaktyki Chorób Piersi w zakresie profilaktyki chorób nowotworowych. J Oncol. 2011;61(5):449-57.

9. Zych B, Marć M, Binkowska-Bury M. Stan wiedzy kobiet po 35 roku życia w zakresie profilaktyki raka piersi. Prz Med Uniw Rzesz. 2006;1:2733.

10. Lewandowska A, Mess E, Laufer J. Profilaktyka raka piersi wśród kobiet. Onkol Pol. 2011;1:131-4.

11. Smoleń E, Dobrowolska B. Wiedza pielęgniarek województwa lubelskiego i podkarpackiego w zakresie czynników ryzyka nowotworów piersi. Med Og Nauk Zdr. 2014;20(1):6-11.

12. Cichońska M, Borek M, Krawczyk W. Wiedza kobiet w zakresie zapobiegania nowotworom piersi i raka szyjki macicy. Acta Sci Acad Ostrov. 2012;1:5-25.

Corresponding author

Prof. dr hab. Dariusz Matosiuk

4A Chodźki Str., 20-093 Lublin, Poland

E-mail: dariusz.matosiuk@umlub.pl 